\title{
Sweat and Blood: Swordsmanship and sabre in Fribourg
}

\author{
Mathijs Roelofsen, \\ PhD Student, University of Bern \\ mathroelofsen@gmail.com, \\ and \\ Dimitri Zufferey, \\ Independant Researcher, \\ GAFSchola Fribourg, \\ zufferey@protonmail.com
}

\begin{abstract}
Following a long mercenary tradition, Switzerland had to build in the 19th century its own military tradition. In Cantons that have provided many officers and soldiers in the European Foreign Service, the French military influence remained strong. This article aims to analyze the development of sabre fencing in the canton of Fribourg (and its French influence) through the manuals of a former mercenary (Joseph Bonivini), a fencing master in the federal troops (Joseph Tinguely), and an officer who became later a gymnastics teacher (Léon Galley). These fencing manuals all address the recourse to fencing as physical training and gymnastic exercise, and not just as a combat system in a warlike context.
\end{abstract}

Keywords - Sabre, Fribourg, Valais, Switzerland, fencing, contre-pointe, bayonet

\section{INTRODUCTION}

In military history, the Swiss are known for having offered military service as mercenaries over a long time period. In the 19th century, this system was however progressively abandoned, while the country was creating its own national army from the local militias.

The history of 19th century martial practices in Switzerland did not yet get much attention from historians and other researchers. This short essay is thus a first attempt to set some elements about fencing in Switzerland at that time, focusing on some fencing masters from one Swiss Canton (Fribourg) through biographical elements and fencing manuals. The city of Fribourg saw the development of a vivid fencing scene over the 19th century, due to popular demand and, at least partially, to the martial experience gained in Foreign Service. Three fencing masters are known for having published sabre manuals, showing strong French influences. To address the development of fencing in the region of Fribourg (especially its city) and the influence of the French fencing and military traditions, we will analyze these three fencing masters' manuals and their links with the local fencing and military context. The manual of one of the three fencing masters, Joseph Tinguely, also gained lately some attention from the international HEMA community. This essay will thus also shortly address the legacy of a 19th century fencing master in the reviving of his method in other spaces and our time period. 


\section{FOREIGN SERVICE}

To understand the context of the development of sabre fencing in the region of Fribourg, we need to address first the martial context of the Swiss Foreign Service and its place in some of the masters' martial background.

The Service de France is overwhelmingly represented in Swiss mercenary history. Diplomatic agreements such as the Paix perpétuelle of 1516, the Franco-Swiss alliance of 1521 and capitulations (the General Capitulation of 1553 was in force until 1671) established state driven systems of recruitment. Swiss mercenaries participated in large numbers in the Religious Wars (1562-1598), both on the Catholic and Protestant sides, but did not meet during battles. Specific officers were needed to handle the relations between the French government and the Cantons: for example, in 1571, Charles de Montmorency-Damville (1537-1612) was appointed Colonel général des Suisses et Grisons. This lucrative and honorary position was occupied by members of the French nobility. Over the following centuries, the diversification in Foreign Service increased: many capitulations were signed with Spain (during the Thirty Years' War), Genoa, Savoy, Venice, Bavaria, Saxony and Sweden. However, criticism about mercenaries increased at the end of the Napoleonic 1st Empire. The restoration of monarchies on the country's borders and the development of nationalism gave birth to a patriotic sentiment in the beginning of the République Helvetique. The new institutions and the general opinion broadly condemned Foreign Service.

\section{II.1. The end of Foreign Service}

Despite the critics, Foreign Service was still practiced during the early 19th century, bringing military influences from whole Europe into the newly created Swiss federal army. The decline began however around 1815, with the disappearance of the Service of Savoy. The next Service to be revoked was the one in England in 1816. It was followed by the Spanish Service in 1823, which was abolished by the decree of the Cortes. For its part, the Dutch Service continued until 1829 (capitulation of four regiments in 1814). The two most durable services were the Service of the Pope (two regiments capitulated in 1832, dissolved in 1849, during the Roman revolution, and then rebuilt under the name of Foreign Regiments until 1870) and that of the Kingdom of Naples, which disappeared in 1789, reappeared in 1825, and then was abolished in 1859.

The end of the Service of Naples finally leads to the abolition of Foreign Service. The prohibition of all forms of mercenaries (without the authorization of the Federal Council) was promulgated in 1859 (however still present today in very marginal forms, such as the Swiss Guard in the Vatican).

\section{II.2. The de Courten Regiment and its relationship to martial skills}

These years of Foreign Service saw the development of martial knowledge alongside the officers. It is difficult to find traces of their training in the handling of weapons and of the transmission of martial knowledge. However, one of these testimonies can be found 
in ex-libris ${ }^{1}$ associated to an officer serving in a de Courten ${ }^{2}$ regiment, which are found on editions of fencing and military books such as Le Nouveau traité des Armes by Nicolas Demeuse of 1778 or l'Essai sur la Tactique de l'Infanterie by Gabriel Pictet of Geneva of 1761. Following the idea of Swiss knowledge acquired on the fields, it should be noted that Gabriel Pictet (1710-1782) participated in the training and formation of the Légion des Troupes Légères (France) in 1776 (satisfied with his work, Victor Amédée III appointed him Brigadier Général).

A letter dated form the 13th of September 1821 shows that a lieutenant of the de Courten's regiment presented the same interest: Pierre de Riedmatten, who joined the French Foreign Service but was not really suited for a military career, as he seemed more a source of embarrassment for his family (especially because of his debts and his reluctance to do any military service). In his letter, de Riedmatten addresses a request to the Count Antoine Joachim Eugène de Courten (1771-1839):

General, Being very firmly resolved not to omit anything that could contribute to erasing the weakness I had in September 1817 with Mr. Stokard, providing further, that in the first days of my release I could be exposed to many inconveniences from Mrs. the officers, I ask you to allow me that during the time that the suspension of my freedom will last, I take some weapons lessons from Mr. Müller, so that whatever the events are, I can at least act defensively.

I very willingly consent to a reduction in my pension for savings sacrifice to fencing lessons, which I believe are essential to take. If you accept my request, I take the liberty of asking you to please charge someone to make an agreement with Mr. Muller and provide me with the foils, as well as the other necessary items.

The benefice I would get from them is important and I therefore do not hope to be able to obtain this condescension from you. I have the honor of being your very humble servant. ${ }^{3}$

${ }^{1}$ Information obtained with a research on the rare book sales website www.abebooks.com, made on the 12th December 2018.

2 The de Courten Regiment was a Swiss infantry regiment mainly in the Service of the Kingdom of France and created in 1690. The de Courten family frequently played a role in Valais local and cantonal politics, more rarely in national politics.

3 The letter explains: "Mon général, Étant très fermement résolu de ne rien ommettre qui peut contribuer à éffacer la faiblesse, que j'ai eue au mois de [septembre] 1817 avec M. Stokard[?], prévoyant en outre, que dans les premiers jours de ma sortie je pourrais être exposé à bien des désagremens de la part de MM. les officiers, je vous prie de permettre que pendant le temps que durera la suspension de ma liberté, je prenne des lecons d'armes de M. Müller, afin que quelques soient les évenemens, je puisse au moins agir défensivement. Je consens très volontiers, à ce que j'éprouve une diminution dans ma pension, pour sacrifice d'épargne aux lecons d'escrime, que je 
A notice on the top left of this letter tells us that de Courten responded negatively to this request. The person cited in the letter was probably Captain Alexandre Müller, a cavalry officer who published various treatises on sabre for the cavalry and bayonet handling. Although other sources in the State Archives of Valais concerning the de Riedmatten's case do not provide us with more information on the matter of training, the letter shows the interest of a Swiss officer for a French method. It is then not a surprise to observe this type of attention among other Swiss officers and fencers, notably in the Canton of Fribourg.

\section{FENCING IN FRIBOURG}

Fribourg is no different from any other Swiss city in terms of fencing tradition. The Canton and the city of the same name provided mercenaries to other nations. The patrician regime found a solution to the economic crisis and famines in the 17th century through Foreign Service. The peasants in excess, young, well fed and strong, were praised as soldiers to the King of France. In exchange, it guaranteed a supply of salt to Fribourg, a strategic commodity for farmers and cheese makers. The local aristocracy, specializing its members in the profession of arms, supervised the troops provided to France ${ }^{4}$. This exchange system, perfectly integrated by the State, has left its mark on the culture and landscape of Fribourg to this day.

It should be recalled that in 1798, during the French invasion of Switzerland, Swiss military forces only comprised militias from the different Cantons. After the Sonderbund War in 1847 (Swiss civil war) and the 1848 Constitution, the country needed a new national and more centralized army. The supervision of this new federal army was ensured from the middle of the $19^{\text {th }}$ century by professional officers, who relied on military experience gained during Foreign Service.

\section{III.1. First master in the canton of Fribourg}

To fully understand this culture of weapons, we must also look at the the first traces of fencing and masters of arms. If in France, corporations were like the other trades, the Holy Empire saw the constitution of three brotherhoods (Marxbruder, Federfechter, Luxbruder), which will not be attached to a territory. This did not prevent cities from establishing regulations for the conduct of activities, public interventions (Fechtschulen). At their start, these brotherhoods were only supposed to include teachers and apprentices,

crois indispensable de prendre. Si vous aquiéscez à ma demande, je prend la liberté de vous prier de vouloir bien charger quelqu'un, qui fasse un accord avec M. Muller et qu'il me procure les fleurets, ainsi que les autres objets nécessaires, le fruit que j'en retirerais est important et je me desespère donc pas de pouvoir obtenir de vous cette condescendance. J'ai l'honneur d'être avec [?] eyent, votre très humble serviteur [...]" See Lettre du lieutenant de Riedmatten (le fils), 13 septembre 1821(all English translation were made by the article's authors).

${ }^{4}$ See Steinauer, Patriciens, fromagers, mercenaires. 
but pupils themselves claimed to belong to one or the other category (probably that of their teacher).

For Switzerland, it is a mixture of these two influences with the additional disadvantage of not having a city of enough critical size (like Paris, Lyon or Frankfurt) to have given rise to a professional grouping of weapons masters. In French-speaking Switzerland, whether in Lausanne, Neuchâtel, or Yverdon, forms of practice very similar to those of the Kingdom of France exist. And in German-speaking Switzerland, there are no major differences with the other regions of the Holy Empire.

Fribourg with its bilingual position, is at the crossroad of these two influences. Walter Schaufelberger, in his analysis of fencing ${ }^{5}$ in Switzerland, draws the career path of fencing masters and schools. There are indeed some references in Fribourg's archives, for example in this act of engagement of a French master in 1707:

Mr. Anthoine de Luc, dit Chevallier, born in la Reole in the province of Guyenne, maistre d'armes, is well-behaved and as long as it will be any, it will be great to practice his fencing art here in his workshop and to instruct the youth ${ }^{6}$.

However, no specific fencing system to the region emerged, at least for the longsword. In the 19th century, with the emergence of new forms of fencing and the use of new weapons such as the sabre, the staff or the bayonet, things began to change.

\section{III.2. When the sabre arrives in Switzerland}

The first occurrence of the word sabre in the Swiss press ${ }^{7}$ appeared in January 1813 in the Zürcherisches Wochenblatt. A person named "Collet", master of arms, offers sword, sabre and contre-pointe courses. Concerning Swiss fencing manuals, it was the Colonel Johannes Wieland who, in his 1825 Manuel militaire, published the first written bases for Swiss sabre fencing. However, looking at the Swiss fencing manuals published between 1800 and 1850, the handling of the bayonet is almost exclusively represented ${ }^{8}$.

\footnotetext{
${ }^{5}$ In Schaufelberger, Der Wettkampf in der Alten Eidgenossenschaft, pp. 141-146.

6 "Mr. Anthoine de Luc, dit Chevallier, natif de la Reole en la province de Guyenne, maistre d'armes, ist uff wohlverhalten und solang es mgh wirdt beliebig sein, tolleriert, sein fechtkunst ellhier in ihrer haubstatt zu uben und die jugend zu underweisen. "Listed in the state archive in Fribourg under the reference AEF, RM 258, 309. See Schaufelberger, Der Wettkampf in der Alten Eidgenossenschaft.

7 All references of Swiss press articles are available in electronic form on the website www.enewspaperarchives.ch.

8 Among all the references, several must be underlined like: the Praktischer Unterricht in der Bajonnettfechtkeunst written by the major Albrecht von Sinner in 1835; the Instruction sur l'escrime à la baïonnette edited by the federal Conseil fédéral de la guerre in 1845, or the Traité sur l'escrime à la bayonnette written by an officer from Neuchâtel, Rougemont in 1852.
} 
Sabre fencing was more present in the second half of the 19th century. The contre-pointe is a term that will be widely used when announcing competitions in Valais. For example, in 1853, the Société cantonale d'escrime gave "a pointe, contre-pointe and staff match"“ (Courrier $d u$ Valais, 17th March 1853). These demonstrations and courses will abound throughout the century throughout Switzerland.

Focusing on the case of Fribourg, the arrival of fencing masters did however create some problems. Still enclosed within its walls, the city of Fribourg, despite the end of the patriciate, remained conservative in its values.

In 1828, a citizen proposed to hire two fencing teachers in parallel with the creation of a boarding school. The clergy replied that such a proposal was "immorale, affreuse, abominable". The situation had changed, however, in 1833, as there were indeed two masters of arms working at the boarding school. In the same newspaper article, an anonymous citizen wondered how "we can run away today from what he condemned four years ago 10" (Journal du canton de Fribourg, 9th April 1833). In October 1845, Le Narrateur fribourgeois published an advertising in which Florent Schill, master of arms, was still looking for students. On 18 December 1849, the Fencing Society of Fribourg was mentioned for the first time. On an assaut d'armes, its president and master of arms, displayed his mastery of "pointe, contre-pointe et bâton" (Le Confédéré de Fribourg, 18th December 1849). In 1854, Pierre Schneuwly won first place in pointe fencing at the Federal Gymnastics Festival (Le Confédéré de Fribourg, 29th July 1854).

Still in the same period, on 16 January 1855, Le Narrateur fribourgeois published a manifesto promoting fencing. It praised the modest fencing Society with its "buts nobles et utiles et ses résultats heureux". Every week, as the paper explains, the "serious and graceful play of the pointe contrasts with the rougher but always courteous gaits of the contre-pointe, and with the agitation of the staff. But all off this has to stop for a moment to make room for the bayonet's martial ${ }^{11}$ ". The first mention of a fencing course in a Catholic school can also be found in the same year (Le Chroniqueur, $3^{\text {rd }}$ March, 1855). Public fencing courses also opened for the Youth: in 1864, the winner of the Federal Fencing Festival opened his own room and offered sabre and foil lessons. Pierre Schneuwly ensures the quality of his course. His announcement shows that he was interested in fencing with both weapons and was able to ensure that "Nothing will be neglected to make [his students] very skilled in the practice of this art ${ }^{12}$ " (Le Confédéré de Fribourg, $2^{\text {nd }}$ March 1864). Ten years later, the press is more concerned about the excesses linked to the practice of mensur, which, from German universities, is spreading to Switzerland. As the mensur is seen as a dangerous

\footnotetext{
9 "un assaut de pointe, contre-pointe et de bâton"

10 “on peut se sauver aujourd'hui avec ce qu'il damnait, il y a quatre ans".

11 “demandsjeu grave et gracieux de la pointe contraste à côté des allures plus rudes, mais toujours courtoises de la contre-pointe, et à côté de la turbulence du bâton. Mais tout cela doit cesser un instant pour faire place aux martiales exigences de la baïonnette”.

12 "rien ne sera négligé pour rendre [ses élèves] très habiles dans la pratique de cet art".
} 
activity fencing is then considerated (like gymnastics) as "Just like gymnastics, an excellent physical exercise ${ }^{13}$ " (Le Confédéré de Fribourg, 13 ${ }^{\text {th }}$ September 1874). The fencing rooms in Fribourg then studied a whole range of weapons related to fencing: sabre, foil, bayonet and staff.

\section{III.3. One Army, one School}

In June 1835, Le Nowvelliste Vaudois recounted the first attempts at a new fencing system in which soldiers armed with bayonets were able to triumph by two or even three riders. Swiss officers, like Major von Sinner, put these attempts into practice. In 1855, in the same newspaper, an editor discusses federal fencing regulations. He suggested some modifications to the 1845 text (Le Nouvelliste Vaudois, $6^{\text {th }}$ June 1835). Military training took more and more space during the $19^{\text {th }}$ century and reforms to properly integrate the experience from Foreign Service veterans were being discussed within the Federal Authorities.

The importance of a good education and training was recognized as early as 1875 when the Confederation generalized the practice of an examination at the time of recruitment. This became an excellent instrument for measuring the level of the troops' education and literacy. The army became a real center for training for young people and allowed the spread of a common knowledge. Federal Colonel Emil Welti (1825-1899) planned a new army system and promoted the centralization of infantry training in the hands of the Confederation alone. He intended to break with the Foreign Service amateurism and imagined the foundations of a nation in arms, according to the traditions attributed to prestigious countries or cities. Inspired by classical reading, Emil Welti intended to place Switzerland halfway between Sparta and Prussia. There was however a strong opposition to military education in schools: “...but we are also convinced that it is not by the handling of the sabre or rifle that [teachers] will ever succeed in obtaining this consideration whose project establishes their new position ${ }^{14 "}$.

The development of a federal army played an important role in maintaining the military knowledge and tradition gained during the Foreign Service, in particular in France: for example, Le Chroniqueur, on $31^{\text {st }}$ December 1856, announced the death of Louis Justin Lafaugère (1782-1856), a French fencing master, who had a student from Fribourg (Bongard, also a well-known fencing master in the region).

13 "un excellent exercice corporel".

14 Ruffieux, Du Noir et Blanc au Rouge et Blanc, p. 42. [...] mais nous sommes également convaincus que ce n'est pas par le maniement du sabre ou du fusil que [les instituteurs] parviendront jamais à obtenir cette considération dont le projet entoure leur nouvelle position”. 


\section{THE MERCENARY, THE FENCING MASTER AND THE GYMNASTICS TEACHER}

The arrival in the city of Fribourg of Joseph Bonivini, a former mercenary emerging from the Canton of Valais, "One of the most skillful weapon masters who have served in Swiss regiments abroad ${ }^{15}$ " (Le Chroniqueur, $3^{\text {rd }}$ March 1855) is the first in a succession of publishing fencing masters in Fribourg. Between 1851 and 1877, three texts were published in this territory and established the foundations of fencing in the city. These three authors also have three different profiles: the first, Joseph Bonivini (?-1855) is a Valaisian officer, renowned as a formidable fencer, who spent a period in the Pope's service and is the only one who actually fought in battles; the second, Joseph Tinguely, who was probably incorporated during a period in the federal armies; the last, Léon Galley (1847-1922), is a European renowned gymnastics teacher. All three published sabre manuals based on French inspirations with, each time, a local application and interpretation.

\section{IV.1. Joseph Bonivini, the seasoned mercenary, combining sabre and bayonet (1851)}

Joseph Bonivini military experience is tied to the Pontifical Army Service. His position as a future officer suggests that his incorporation was voluntary. Moreover, he was not the only member of his family to enlist in the $2^{\text {nd }}$ Foreign Regiment of the Vatican ${ }^{16}$, as there was indeed one another Bonivini from the village of Venthône in Valais in this regiment in 1838. Joseph and his unit went in June 1848 in Vicenza for the Battaglia di Monte Berico, a battle between the Austro-Hungarian Empire and the Republic of San Marco, supported by its allies and pontifical troops.

Back in Switzerland, Joseph Bonivini did not definitively retire from the military world, as he joined in 1850 the federal army in accordance to the requirements of Valaisan legislation for former mercenaries: "As for soldiers returning from Foreign Service, they are incorporated into the regiments where their age would call them and serve there with the rank they have acquired abroad ${ }^{17}$ '. He then joined the reserve at the rank of $1^{\text {st }}$ Second Lieutenant, a rank he gained at the end of his service with the Pope ${ }^{18}$. He returned to Switzerland shortly after the Sonderbund War (Swiss civil war) to become a fencing master in the city of Freiburg. The archives do not however allow us to know why the city's fencing society hired him, where he held his position for a few years. In 1851, he

\footnotetext{
15 “un des plus habiles maitres-d'armes qui aient servi dans les régimens suisses à l'étranger".

16 The only Valaisian regiment in the Pope's service was founded following in 1832. See Steinauer, Romaine Syburra-Bertelleto, Courir l'Europe, Valaisians au service étranger, p. 39.

${ }^{17}$ Calpini, “L’organisation des milices Valaisiannes de 1815 à 1875”, pp.18-19: “Quant aux militaires rentrés du service étranger, ils sont incorporés dans le corps de troupe où leur âge les appellerait et ils y servent avec le grade qu'ils ont acquis à l'étranger".

18 Livre des officiers nommés, 1835-1883.
} 
published a Théorie pour l'exercice du sabre et de la bayonnette. The following year, he left Fribourg to return to his home Canton and continued to practice his art. On $9^{\text {th }}$ December 1852 (three years before his death in february 1855), the former mercenary organized an assaut d'armes on the Place de la Planta in Sion, capital of the canton.

\section{IV.1.1. The Théorie pour l'exercice du sabre et de la bayonnette}

Only one photocopy of Bonivini's text remains within the Fribourg State Archives. This document is part of the collection that belonged to the Sociéte d'escrime de Fribourg and was deposited in the cantonal archives by Paul Juillerat, former president of the Société. The text dates back to 1851 according to an article published in the Courrier du V alais in March 1855. Only Bonivini's signature ("Bonivini, maitre d'armes") allows us to formally link him to the manual. The original text seems to have been a small notebook, lithographed in a cursive font, except for the title page where the print and cursive characters are mixed.

Despite the fame of its author, Bonivini's text probably had only a limited distribution since the only example left remains in these photocopies. Aloïs Landtwing's Bibliographie nationale suisse, a reference for identifying Swiss fencing manuals, does not even list this text.

Bonivini's introduction highlights some important points for fencing in Switzerland:

Excellent treatises were elaborated by the first Masters and it must be admitted that there is very little left to ad after what they did with as much patience as knowledge. However, in my travels, I have noticed that this a not less essential part of fencing, which is particularly suitable for the Military, has generally been neglected. Does this mean that this class of man has to limit itself to the ordinary exercises of weapons inseparable from its state? Would it be prohibited from further development? What's the point of having taken him out of the routine of the early days? What is the point of the intelligent care we give to the improvement of weapons if we neglect those required by the way they are used advantageously? ${ }^{19}$

19 “D’excellents traités furent élaborés par les premiers Maîtres et il faut avouer qu'il reste bien peu à faire après ce qu'ils ont fait avec autant de patience que de savoir. Cependant dans mes pérégrinations, j'ai pu remarquer qu’on avait négligé généralement cette partie non moins essentielle de l'escrime qui convient plus particulièrement au Militaire. Est-ce à dire que cette classe d'homme doive se borner aux exercices ordinaires des armes inséparables de son état? Les perfectionnements lui seraient-ils interdits? - A quoi bon alors l'avoir fait sortir de la routine des premiers temps ? A quoi bon encore les soins intelligents qu'on apporte au perfectionnement des armes si l'on néglige ceux qu'exige la Manière d'en faire un usage avantageux ?’ 
Bonivini maintained in his text that the teaching given to the military is not sufficient and that there is room for improvement. His method is tied to a concept that transformed military fencing into a more sportive form: the practice of fencing as a way to maintain physical condition. This idea is more preeminent at the end of the introduction: "Why the fencing companies that I hope will be formed in all parts of Switzerland would not correspond together, would they not fraternize with the gymnastics societies that have taken such a generous initiative?20". This idea will be put into practice, particularly during the Fêtes fédérales de gymnastique, where fencing is integrated in the competitions.

\section{IV.1.2. Military fencing}

In the twelve parts of his lesson, Joseph Bonivini laid the foundations of a system he probably developed on the battlefield. Gardes, coupés, moulinets compose the basics of his teaching. Bonivini wanted to offer a set of short but essential techniques. Unlike other authors, he only keeps in tierce and quarte, which should be sufficient to ensure good protection. It places more emphasis on développés and feintes, parades and ripostes.

The manual does not detail the ideal weapon's form for sabre fencing. The only indications on the weapon are present at the moment when he proposes the moulinet: "We must choose a sabre which tip weighs little, as this makes the wrist loose. A wide sabre in the hand of the student who starts, is in my opinion, the best: this way the student learns better to form the parries with the edge ${ }^{21}$ ". Bonivini also does not bother with the concepts of pointe and contre-pointe. He explains in the preamble:

If my lesson, which I have tried to simplify, seems brief, dry and sterile to some people, it is because it requires prior knowledge both in theory and in practice. In a word, it is because it is addressed to the Société d'escrime de Fribourg, to whom I offer it as a token of my esteem and gratitude ${ }^{22}$.

He conceived his manual as an aide-mémoire in which the presence of a fencing master is essential. Bonivini also introduced a non-military exercise in his instruction: the Wall (le Mur), which allows the student to prove his fencing skills by showing a series of techniques.

\footnotetext{
20 "Pourquoi encore les sociétés d'escrime que j'espère voir se former sur tous les points de la Suisse ne correspondraient, ne fraterniseraient-elles pas avec les sociétés gymnastiques qui ont pris si généreusement l'initiative ?"

21 "on doit choisir un sabre dont la pointe pèse peu, cela fait délier le poignet, un sabre large dans la main de l'élève qui commence, est à mon avis, le meilleur, l'élève apprend mieux par ce moyen à former les parades avec le tranchant”.

22 'Si ma leçon que je me suis efforcé de simplifier paraît à quelques uns, brève, sèche, stérile, c'est qu'elle suppose des connaissances préalables tant en théorie qu'en pratique. C'est en un mot parce qu'elle s'adresse à la Société d'escrime de Fribourg à qui je l'offre comme un témoignage de mon estime et de ma reconnaissance".
} 
He did not however detail the ideal weapon to use during his training sessions, he only specifies: "The sword on the left side between the thumb and forefinger [...] grab the sabre with the right hand". The terms used to define the weapon are also mixed, even if the word "sabre" is used in much greater occasions.

Bonivini's knowledge of other manuals is more visible in the bayonet handling part of his treatise:

The troop being already trained in the manoeuvres of the squares and in forming the skirmisher groups, we only have to observe Mr. Müller's treatise $e^{23}$ on this subject. The instructor, knowing the handling of the bayonet, will quickly learn the mechanism, the defense against the cavalry, treated by Mr. Müller ${ }^{24}$.

The officer, like his counterparts in the de Courten Regiment, knew the French officer's text. He even adds that the troops are trained with this method. The bayonet part of the manual is organized in the same way as the sabre one, as both have to be read as military drills. Still, Bonivini's objective, through his book, is to leave a trace and a memory to his friends. He also initiated a system inspired by his military experience.

\section{IV.2. Joseph Tinguely the fencer and the contre-pointe (1856)}

Very few details are known on Joseph Tinguely's life. His name does not appear in the Schaffroht collection of Federal Military Library (Bibliothèque militaire fédérale Am Guisanplatz), which contains the most references to Swiss officers in Foreign Service. The only information we can gather come from his fencing manual, published in 1856 in Payerne, in which he claims the title of Master of Arms. Among the few elements that appear in this text, there is his probable incorporation into the federal army. The mass of homonyms mentioned in Fribourg's and Waldensian's press between 1800 and 1900 do not help to gather more information on him.

\section{IV.2.1. The Manuel d'escrime à la contre pointe, composé pour les officiers de toutes armes}

The manual is not Tinguely's only writing. Indeed, three years before the publication of his famous manual, he published a first 16-page booklet soberly titled Traité d'armes ${ }^{25}$ (printed by L. Stephan's in Dissenhofen). Unfortunately, this book is not referenced in any Swiss library or archival institution.

\footnotetext{
23 Alexandre Müller, Maniement de la baïonnette, pp. 27 ss.

24 "The troop being already trained in the manoeuvres of the squares and in forming the skirmisher groups, we only have to observe Mr. Müller's treatise on this subject. The instructor, knowing the handling of the bayonet, will quickly learn the mechanism, the defense against the cavalry, treated by Mr. Müller".

25 as shown in Landtwing, Bibliographie Nationale Suisse.
} 
It should be noted that Tinguely's work is from our three sources the one that has the most impact in the HEMA community today. The fact that the Manuel d'escrime is referenced in Landtwing's bibliography and was digitized by Google allowed its appropriation by the HEMA scene. On the other side, Bonivini's work is pretty much unknown by practitioners ${ }^{26}$. Tinguely's manual has recently been translated into English ${ }^{27}$ by Chris Slee, with the advice and support of Julien Garry (de Taille et d'Estoc, Dijon). In his studies of the sabre de bord, the latter fills the gaps in the knowledge of this topic by using Tinguely's manual. Together with St. Martin's and William Pringle Green's manuscripts, these texts provided a basis for the study of fencing in a naval context. Julien Garry also came to demonstrate the application of these texts within the GAFSchola association in Fribourg ${ }^{28}$. Tinguely's text is definitely associated with naval fencing today, as for example, in the French island of Mayotte, where the HEMA club of the Flibustiers de Lémurie sees it as an excellent complement to the sailor's manuals ${ }^{29}$. As early as 1907, in the eleventh edition of the Marin Fusilier Manual, sabre fencing was replaced by swimming, gymnastics, boxing and wrestling.

\section{IV.2.2. A Swiss contre-pointe}

Joseph Tinguely is the only one of our three authors to explicitly mention the notion of contre-pointe fencing in his title. His manual also focuses solely on sabre fencing, while the other two masters associated it with one or two other weapons.

${ }^{26}$ It is not mentioned in the Hungarian database, which is widely used by the HEMA community (www.middlegaes.hu).

27 The English translation of the Manuel of Tinguely is available on the following link: : http://www.longedgepress.com/uploads/7/2/7/2/72721877/tinguely manueldescrimealacontre pointe 1856 final.pdf (consulted on the 22th December 2018).

28 This workshop received the visit of a journalist from the Swiss Radio Television, who made a report on the news, https://www.rts.ch/play/tv/12h45/video/jouer-aux-chevaliers-aux-piratesou-aux-mousquetaires-les-arts-martiaux-historiques-sont-enseignes-a-fribourg?id $=9753517$ (consulted on the 14th December 2018).

29 See the blog of the HEMA Association from Mayotte, les Flibustiers de Lémurie: https://flibustiersdelemur.wixsite.com/flibustiersdelemurie/single-post/2017/07/14/Manuel-dumarin-fusilier (consulted on the 14th December 2018). 


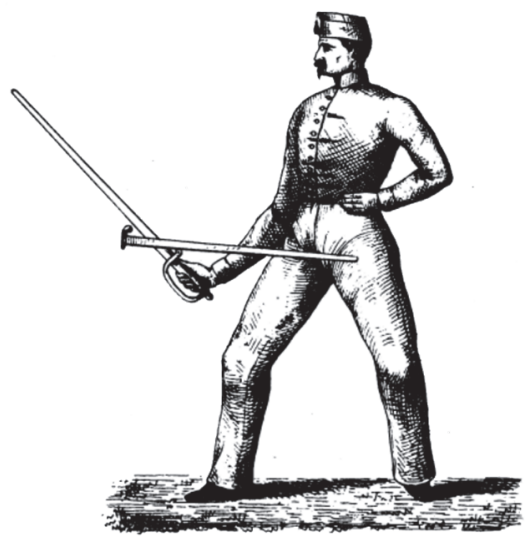

Figure 1 : Joseph Tinguely, Manuel d'escrime à la contre-pointe (1856), simple parry in low quarte, plate 7

If Bonivini and then Galley explicitly mentioned the aims of their work, Joseph Tinguely limited his introduction to a single page. It however certainly makes the link between sabre fencing and physical activity, "un des moyens les plus propres à procurer un exercice excellent ${ }^{30}$ ". Tinguely's manual is part of a French tradition of contre-pointe fencing, which is defined in the Dictionnaire de l'armée de Terre gave a broad definition in 1843:

The contre-pointe differs from the espadon, or rather from the espadonnement, as it has narrower parries, and combines cuts and thrusts, while espadon masters do not practice this kind of play ${ }^{31}$.

This type of fencing was also described in the early work of Alexandre Valville, who opposed smallsword to espadon. His 1817 text $^{32}$ shares a common ground not only with Tinguely's manual, but also with later French manuals, such the one written by Romuald Brunet $^{33}$ (1884). Brunet divided his treatise into two parts, first the pointe (sword and foil) and then the contre-pointe (sabre), with a clear opposition between the two systems. He also presents his treatise as "A branch of fencing essential to any soldier armed with the sabre ${ }^{34 "}$. The contre-pointe is a sabre fencing system using both cuts and thrusts. Tinguely actually devoided his system of moulinets, which differentiates him from his contemporaries, but relied mainly on thrusting. Not only did he create a unique fencing

\footnotetext{
30 "One of the most appropriate way to provide an excellent exercise".

31 “La contre-pointe diffère de l'espadon, ou plutôt de l'espadonnement, en ce qu'elle a des parades moins larges, et se combine avec des coups de taille et d'estoc, tandis que les maîtres d'espadon ne pratiquent pas cette sorte de jeu".

32 Valville, Traité sur la Contre-pointe.

33 Brunet, Traité d'escrime. Pointe et contre-pointe.

34 "une branche de l'escrime indispensable à tout militaire armé du sabre".
} 
style, but like other authors he also transposed a French fencing tradition into a Swiss martial context. The Swiss contre-pointe was later used in military manuals such as the 1867 l'Instruction sur l'escrime au sabre (contre-pointe).

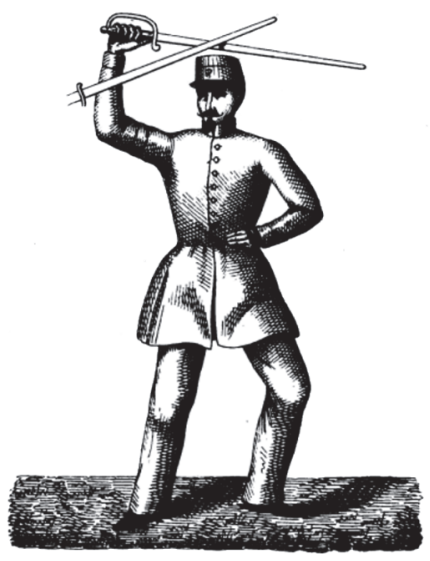

Figure 2 : Joseph Tinguely, Manuel d'escrime à la contre-pointe (1856), simple parry in quinte, plate 9

\section{IV.3. Léon Galley, the promoter of fencing, gymnastics and dance (1877)}

Leon Galley first made a name as a fencer through competitions (Le Confédéré de Fribourg, 4th September 1868), but also through his skill in bayonet fencing, contrepointe fencing and gymnastics. He also was a gymnastics teacher in the schools of Fribourg. Those skills brought him to the head of the Société de gymnastique Fribourg Ancienne. In addition to his activity as a gymnast, his treatise tells us that he was in 1877, 1st lieutenant in the 16th Battalion.

His results in the federal gymnastics festivities and judge roles in European competitions led him to leave Switzerland and settle in Reims (1877-1880). “With Léon Galley from Fribourg, the scientist technician, professor at the Gauloise de Reims, whom I am happy to have given to the Société de gymnastique et d'armes d'Arras ${ }^{35}$ ". He remained in Arras between 1880 and 1887. In ten years, he published "...a gymnastics terminology, codirected by the first French training course for instructors, which reformed the rules of gymnastics meetings on the Swiss model and promoted the participation of Swiss companies in French gymnastics festivals ${ }^{36 "}$.

35 Nord Sportif, 10th February 1904, referenced in les Grandes figures sportives, p. 21: "Avec Léon Galley de Fribourg, le savant technicien, professeur à la Gauloise de Reims, que je suis heureux d'avoir donné à la Société de gymnastique et d'armes d'Arras".

${ }^{36}$ Alexandre Fontaine, Aux heures suisses de l'école républicaine, p. 198: “ [...] une terminologie de gymnastique, codirige le premier cours français de formation pour moniteurs, réforme les 
He chose to return to his hometown with a project in mind in addition to his gymnastic activities. The Communal Council appointed him master of gymnastics (La Liberté, 11 $1^{\text {th }}$ November 1887). This promoter of sports wanted to offer the city its first thermal baths (which will be called Bains Galley), with the addition of a swimming school (Le Confédéré de Fribourg, $1^{\text {th }}$ January 1888). At the turn of the $20^{\text {th }}$ century, Léon Galley gradually left the field of fencing to join another activity, as he also gave dance lessons. At his death at the age of 75 ( $\mathrm{La}$ Gruyère, 22th August 1922), the man was a notable figure in the city.

\section{IV.3.1. The Traité d'escrime pratique au sabre, à la baïonnette et au bâton.}

Léon Galley is the one of our three authors who published the most, always with an emphasis on the necessity of gymnastics as condition for good physical condition. A review of his fencing manual in the Confédéré de Fribourg details:

The author, who takes as his motto: "Glory to God, Fidelity to the Fatherland, Honour to the Arms, Respect to the Masters," dedicates his treatise to gymnastics societies and the military, and demonstrates in his introduction that fencing is, with gymnastics, one of the best and most beneficial physical fortifiers ${ }^{37}$.

Among the works he left us (in addition to his many interventions and rule sets in the field of gymnastics) Léon Galley published in 1898 a Traité des exercices de natation for schools. Following his career path, the bibliography of our sport promoter perfectly illustrates his intentions. He lived and worked for multiple sporting activities.

Concerning fencing, his manual focuses on weapons "Which, by their marked usefulness, have a special meaning nowadays, both from a military and from a practical and hygienic point of view ${ }^{38}$ ". In their manuals' introductions, Galley and Bonivini share the opinion that officers of their time have poor martial skills. The gymnastics teacher does not spare the officers of the Swiss army, "Most of whom, he says, do not know enough about sabre fencing 39 ".

The public reception of Léon Galley's text can be observed in two reviews in the cantonal press. While Le Confédéré de Fribourg acknowledged its shortcomings in evaluating the quality of the method or the technics proposed by Léon Galley, it admits that his explanations "Also have the merit of being presented with great clarity and simplicity,

règlements des rencontres de gymnastique sur le modèle suisse et impulse la participation de sociétés suisses aux fêtes françaises de gymnastique ".

37 “L'auteur, qui prend pour motto : "Gloire à Dieu, Fidélité à la Patrie, Honneur aux Armes, Respect aux Maîtres, » dédie son traité aux Sociétés de gymnastique et aux militaires, et démontre dans son introduction que l'escrime est, avec la gymnastique, l'un des meilleurs et des plus salutaires foritifiants corporels".

38 “qui, par leur utilité marquée, ont plus spécialement leur raison d'être de nos jours, tant au point de vue militaire qu'au point de vue pratique et hygiénique”.

39 "le plus grand nombre, dit-il, ne connaissent pas suffisamment l'escrime au sabre". 
which makes the treaty accessible to all understanding 40 ". Le Chroniqueur is more lyrical and did not take a position on the text:

Fencing is a strong and sustained exercise that involves all our body, essentially facilitates the development of muscle strength and adds strength to naturally strong men. Indeed, the rough tension in which the fencer's muscles remain, the continuous effort that he is forced to support, make him acquire this promptness, this ease of movement, this easy maintenance, essential conditions of well-being. Fencing also makes the brain act continuously, because attention must always be tense, the glance sharp, the thought quick, the will determined, the decision quick and leading to an instantaneous, frank and bold execution ${ }^{41}$.

\section{IV.3.2. The Swiss version of the Joinville's method}

Léon Galley is the only one of our three authors to have published lessons that can be studied without the help of a teacher, while being extremely detailed. The description of each phase of his lesson uses simple and explicit words as best as possible. He divides his lesson into two parts: a first one where the basics such as guards, position, movements and parries (see figure 3) are explained; the second one ad more complexity with multiple attacks, feints and other moves.

40 “ont de plus le mérite d'être exposées avec beaucoup de clarté et de simplicité, ce qui met le traité à la portée de toutes les intelligences".

41 "L'escrime est un exercice fort et soutenu qui met en jeu tous nos organes, facilite essentiellement le développement de la force musculaire et ajoute de la vigueur aux hommes naturellement robustes. En effet, la tension violente dans laquelle demeurent les muscles du tireur, l'effort continuel qu'il est contraint de soutenir, lui font acquérir cette promptitude, cette facilité de mouvements, ce maintien aisé conditions essentielles du bien-être. L'escrime fait de plus agir continuellement le cerveau, car l'attention doit toujours être tendue, le coup d'œil vif, la pensée prompte, la volonté déterminée, la décision rapide et entraînant une exécution instantanée, franche et hardie.” 


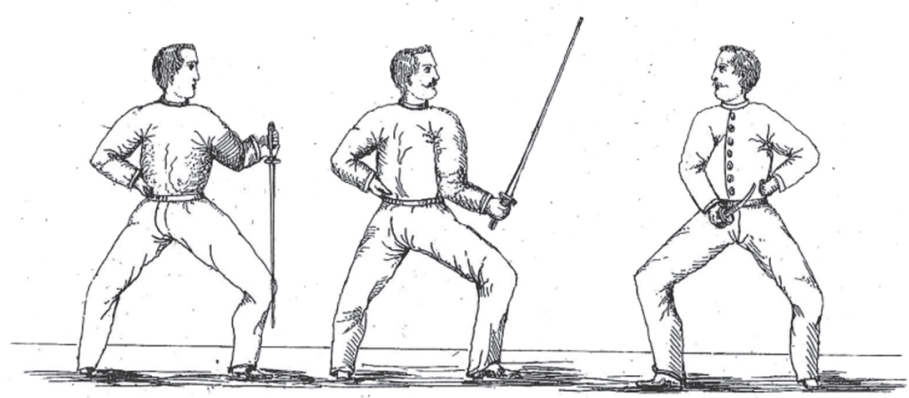

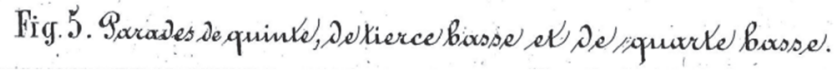

Figure 3 : Léon Galley, Traité d'escrime pratique au sabre (1877), parries

However, the contre-pointe in the manual is a specific part of the blade, and not a fencing system: "The sabre has, so to speak, two cutting edges: a strong and a weak one. The strong is understood from the guard to the middle, and the weak is taken from the middle of the blade to the point. The back of the sabre is the part opposite the edge in the strong part; in the end of the weak part, both edges are natural; this part is called the contrepointe ${ }^{42}$ '.

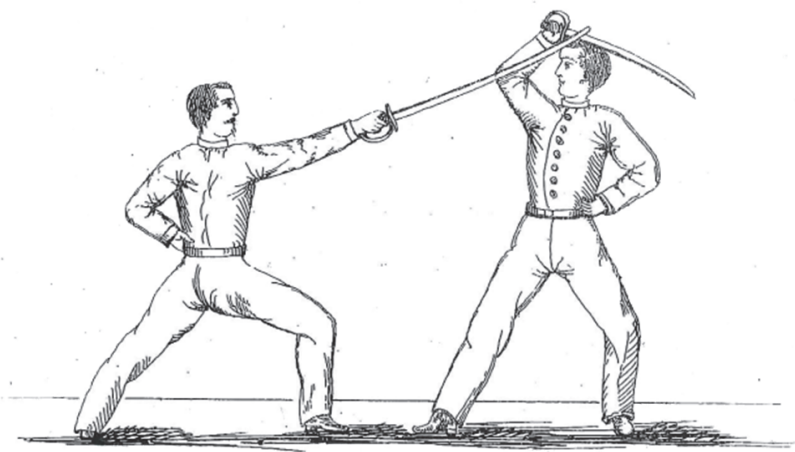

\section{Fïg: 2. Comp dexêle ew développant, paradeda prime awec retroxite de corpis.}

Figure 4 : Léon Galley, Traité d'escrime pratique au sabre (1877), strike at the head, prime parry

More generally, the division of Galley's method is similar to a fencing manual published by the French Ministry of war in 1877. Galley agreed with the proposal of Joinville's

\footnotetext{
42 "Le sabre a, pour ainsi dire, deux tranchants : un fort et un faible. Le fort est compris depuis la garde au milieu, et le faible se prend du milieu de la lame jusqu’à la pointe. Le dos du sabre est la partie opposée au tranchant dans la partie forte; dans l'extrémité de la partie faible, les deux tranchants sont naturels; cette partie s'appelle contre-pointe."
} 
military school specialists by giving an important place to the assaut, or more simply to the Mur, which was inspired by the military school; some terminology, such as reprise for naming the exercise, was also taken from Joinville. The fencing master also used the mottoes proposed in the 1877 Manual on the cover of his book: "Respect for the Masters [...] Honor to the Arms ${ }^{43}$ ".

The links between Joinville's school and Léon Galley are also visible in his part on the staff, which shares the same exercises as the French fencing manual. These links can be explained by the fact that Galley was still in France when his manual was published.

\section{TOWARDS THE FENCING ROOM FOR MILITARY PERSONNEL}

The three manuals all share a common ground: they all concern the practice of sabre fencing, are published in the same geographical and linguistic space and are written by individuals involved both in the military and the city's fencing scene.

Despite being written in the same period, these texts do not approach sabre fencing the same way. Each author's background had a major influence on the fencing system described in each one's manual. While Tinguely and Galley clearly had great French inspirations, Bonivini's choices may come from his experience on the Italian battlefields. The press of that time shows that in a small Swiss city like Fribourg, many fencing courses flourished. Young people practiced what was becoming more and more a sport. As we didn't find the programs of these courses yet, these three methods are a precious source to understand of the practice of sabre fencing in the region.

The public was also is invited to come and judge the performance of the masters and officers. Fencing left the battlefield to enter fencing rooms. The practice of the square, this solo exercise very popular in military training, disappeared in Bonivini's manual, focusing more on a master-student relationship. Galley, on the other hand, offered a method that can be practiced without the help of a master. Unlike Bonivini and Galley, Tinguely did not propose the exercise of the Mur, but focused on assauts. In his last paragraph on Practical Observations, hi gave a valuable advice to the student fencer: "Never longe yourself too much, as this prevents you from getting back in position ${ }^{44 "}$ " or "The distance from your ward must be moderate ${ }^{45 "}$. Putting the emphasis on the observation of the other fencer, Tinguely thus proposed a system that moves away from the battlefield to go into the fencing room but remained practiced in the military.

In the end sabre fencing merged with the more sportive concept of physical training. Léon Galley is a perfect example of this evolution, as he adapted himself to his time and

\footnotetext{
43 Manuel d'escrime, p. 126: "Respect aux Maîtres [...] Honneur aux armes".

44 "Ne vous fendez jamais trop, car cela vous empêche de vous remettre lestement en garde"

45 "la distance de votre garde doit être modérée"
} 
gradually focuses on the practice of gymnastics and especially on good body hygiene. As schools were still training young people to become good soldiers, the development of gymnastics generated vivid debates in the politics and in the newspapers. However, the textbooks at the turn of the 20th century have evocative titles: Manuel de gymnastique pour l'instruction militaire préparatoire de la jeunesse suisse. These texts, adopted by the Authorities, provide for numerous exercises of movement and exercises with an iron cane of 2 to $3 \mathrm{~kg}^{46}$.

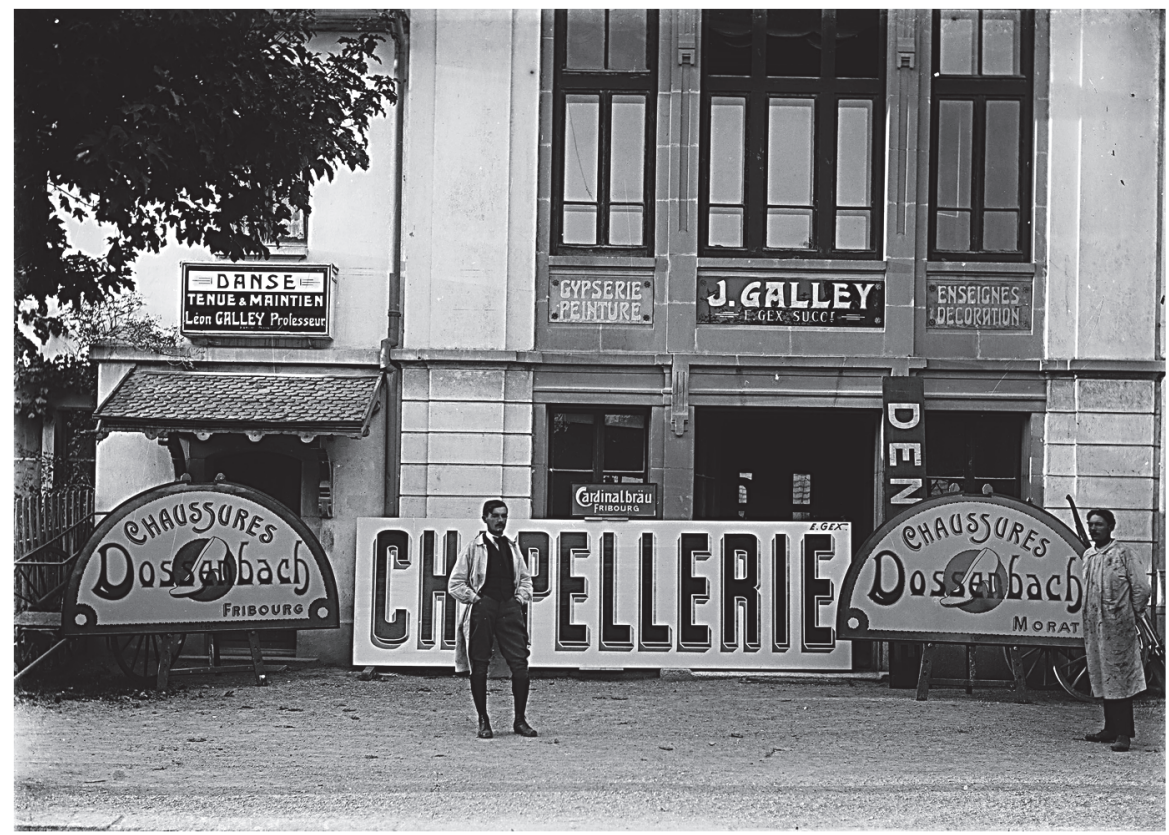

Figure 5 : Prosper Macherel "Salle de danse de Léon Galley et atelier de peinture J. Galley an quartier d'Alt, avenue de Rome 11, Fribourg", [Ca. 1904] Credits : Prosper Paul Macherel (C) Bibliothèque cantonale et universitaire Fribourg.

Also, let's not forget that the sabre, like the sword, remained a symbol of power. In the 1891 Swiss Infantry Exercise Regulations, the use of the sword is explained only for parades, salutes:

When you have to make a report or receive orders, make a step towards the superior.

Withdraw and raise the sabre.

Take the sabre back from the right $\operatorname{side}^{47}$.

\footnotetext{
46 Manuel de Gymnastique, pp. 25-50.

47 Règlement d'exercice, p. 28: “Lorsqu'on va faire un rapport ou recevoir des ordres, il faut s'approcher à un pas du supérieur. Se retirer et relever le sabre. Reprendre le sabre du côté droit."
} 


\section{BIBLIOGRAPHY}

\section{VI.1. Primary sources}

Note for Swiss press articles: All article references are available on the database of the digitized Swiss press: https://www.e-newspaperarchives.ch or on the database from the Cantonal and University Library in Lausanne: https://scriptorium.bcu-lausanne.ch.

AEF State Archive of Fribourg, Fribourg

AEV State Archive of Valais, Sion

BiG Bibliothek am Guisanplatz, Bern

\section{VI.1.1. Sabre sources from the canton of Fribourg}

Joseph Bonivini, Théorie pour l'exercice du Sabre et de la Bayonnette, [1851], [Photocopy of the booklet] CH AEF Carton 126.7, Fribourg.

Léon Galley, Traité d'escrime pratique au sabre, à la baïonnette et au bâton, Fribourg: Imprimerie Galley, 1877.

Joseph Tinguely, Manuel d'escrime à la contre pointe, composé pour les officiers de toutes armes, Payerne : Imprimerie Ch. Caille, 1856.

\section{VI.1.2. Archives}

Bonivinis, Sammlung Schaffroht, [s.d.], Cote BiG-SIG-DU-03347, Bibliothek am Guisanplatz, Bern.

Lettre du lieutenant de Riedmatten (le fils), adressée au comte de Courten, colonel du $8 \mathrm{e}$ régiment de la Garde royale, à Orléans, 13 septembre 1821, CH AEV, de Courten, Cn B 15/4/13, Sion.

Livre des officiers nommés, 1835-1883 (annexe IV), CH AEV, 2 DM, 61, Sion.

\section{VI.1.3. Fencing and military manuals}

Romuald Brunet, Traité d'escrime. Pointe et contre-pointe, E. Rouveyre \& G. Blond, Paris, 1884.

[Conseil fédéral], Manuel de gymnastique pour l'instruction militaire préparatoire de la jeunesse suisse de 10 à 16 ans, approuvé par le Conseil fédéral le 6 mai 1898, Lausanne: Imprimerie Lucien Vincent, 1899.

[Conseil fédéral], Règlement d'exercice pour l'infanterie suisse, arrêté du Conseil fédéral du 23 décembre 1890, Syndicat des Maitres imprimeurs de la Suisse Romande, 1891.

[Département militaire fédéral], Instruction sur l'escrime à la baïonnette, Bern: Département militaire fédéral, 1845.

[Département militaire fédéral], Instruction sur l'escrime au sabre (contre-pointe), Bern: Département militaire fédéral, 1876.

[Ministère de la guerre], Manuel d'escrime approuvé par le Ministère de la Guerre, le 18 mai 1877, Paris: Imprimerie nationale, 1892. 
[Ministère de la guerre], Manuel du Marin Fusilier, onzième édition, Paris: Imprimerie nationale, 1907.

Alexandre Müller, Maniement de la baïonnette appliqué à l'attaque et à la défense de l'infanterie, Paris: Anselin Libraire, 1828.

Rougemont, Traité sur l'escrime à la bayonnette, se divisant en quatre leçons, Neuchâtel: Imprimerie de Frédéric Loutz, 1852.

Alexandre Valville, Traité sur la Contre-pointe, Charles Kray, St. Petersburg, 1817.

Albrecht von Sinner, Praktischer Unterricht in der Bajonnettfechtkunst. Der schweiz: Infanterie gewidmet, Bern and Chur: J.F.J Dalp, 1835.

Johannes Wieland, Manuel militaire pour l'instruction des officiers suisses de toutes armes ou essai d'un système de défense de la Confédération helvétique. Avec une petite carte de la Suisse et quatre plans sur les mouvements de troupes et manouvres de combat. Traduit de l'allemand, sur la seconde édition et sous les yeux de l'auteur par V. Kuenlin, Geneva: J.J Paschoud, 1826.

\section{VI.2. Secondary sources}

Jacques Calpini, "L'organisation des milices Valaisiannes de 1815 à 1875" in Vallesia, Sion, t.18, 1963, pp.1-118.

Christian Dorvillé [éd.], Grandes figures sportives du Nord-Pas de Calais, Lille: Septentrion, 2010.

Alexandre Fontaine, Aux heures suisses de l'école républicaine, Un siècle de transferts culturels et de déclinaisons pédagogiques dans l'espace franco-romand, Paris: Éditions Demopolis, 2015.

Aloïs Landtwing, Bibliographie Nationale Suisse, Exercices corporels, Gymnastique, Escrime, Équitation, Cyclisme, Sports Nautiques, Bern: K. J. Wyss, 1899.

Roland Ruffieux, Du Noir et Blanc au Ronge et Blanc, un siècle d'bistoire militaire fribourgeoise 1875-1975, Fribourg: Imprimerie de Saint-Paul, 1975.

Walter Schaufelberger, Der Wettkampf in der Alten Eidgenossenschaft, 2 Bände, Schweizerheimatbücher, Bern: Verlag Paul Haupt, 1972.

Jean Steinauer, Romaine Syburra-Bertelleto, Courir l'Europe, Valaisians au service étranger, les cabiers du Musée d'bistoire du Valais, Bern: Hier und Jetzt Verlag, 2009.

Jean Steinauer, Patriciens, fromagers, mercenaires, Histoire de l'émigration fribourgeoise, XVIIeXVIIIe siècle, Neuchâtel : Alphil, 2017. 